\title{
The Roles of Factors in Communication Styles Influencing the Marriage of Bataknese and the Javanese
}

\author{
Alice Gunasirini \\ Graduate Program \\ Petra Christian University
}

\begin{abstract}
.
This discussion here is about the different styles of communication in the marriage of the Bataknese and the Javanese. The research is how the Bataknese as the nomads interact in communication in their mix-marriage. To analyze the phenomenon, I will use the theories of communication and acculturation and the method of qualitative. By using the theories and method I will analyze how the Bataknese and the Javanese overcome their conflicts in their marriage due to the differences in communication to reach the harmony in their mix-marriage.
\end{abstract}

Key words: differences, conflicts, communication style, acculturation, harmony.

\section{INTRODUCTION.}

Each ethnic has their own individual cultural pattern that affect their way to communicate. The Bataknese and the Javanese have their own characteristics in communicating.. The Batak nomads and most of the Bataknese who were born in Java have almost the same characteristic of communication. They speak in loud voice that is usually combined with the pointing of their forefinger, directness or to the point and to chase the details to the core of the problem. This style of communication becomes their characteristics or their trademark in communicating.

The Javanese, however, have the opposite style of communication compared to the Bataknese as they speak in soft voice, have convoluted style and tend not to express themselves directly or not as it is. The Bataknese think the Javanese as insincere, difficult to understand and easily get offended while the Javanese consider that the Bataknese as proud, rough and easily get angry. Although not all Bataknese people speak in loud voice, they are practically oriented in the habit of speaking directly and asking questions in details which insult the Javanese. "How can you be so rough?" is their usual reaction and they stay away from the Bataknese.

To improve their friendship with the Javanese, the Bataknese have to come into focus to fix their style of communication which the Javanese dislike. It takes time around one year or two in average to decrease their loud voice into a softer one but unfortunately the same loud voice will reappear when the Bataknese come into contact with their community of Bataknese.

The same problem comes into the surface when the Bataknese marry the Javanese. Their opposite style of communication becomes the central problem in the early stage of their mix-marriage between ethnics. Due to the different styles of communication between the Bataknese and the Javanese, I would like to find out the techniques they use to cope or adjust to each other especially in marriage to reach harmony.

Thus I am going to find out what kind of strategy the Bataknese and the Javanese use in overcoming their differences in communication, to end their conflict by applying the use of acculturation and cross-cultural communication strategy to reach harmony in their marriage.

Communicating across cultures is challenging because the people involved in the interaction are unaware of their own cultural biases and due to cultural imprinting that starts since childhood while some of culture's knowledge, rules, beliefs, values, phobias, and anxieties are taught explicitly, thus most of the information is absorbed 
subconsciously. People are all individuals, and no two persons of the same culture respond exactly in the same manner. However, generalizations are valid to the extent that these manners provide the clues on what others will most likely encounter when speaking with people from different culture. Communication is one the most important things in life. From communication, everything can be connected. However, there are sometimes some hindrances that can disturb the information of the way it is conveyed. How important is communication actually in human life? To be able to communicate well is important. There will be different people to communicate with. It is helpful to consider about how to do these conversations. Whom do people want to share their information with and how? The people to converse with will also have something to tell. They may not know how to tell about what is happening. (retrieved May 25,2018 from https://www.caresearch.com.au/caresearch/ForPatientsandFamilies

/LivingWithIllness/WhyIsCommunicationImportant/tabid/1095/Default.aspx: Last updated 27 November 2017. )

There is a reciprocal connection/relationship between culture and communication, culture influences communication and communication influences culture. In short, one can say that culture is created, formed, transmitted and learned through communication; on the other hand, communication practices are created, formed and transmitted through culture (Raharjo, 2005: 49-51). Communication leads us to meet and exchange symbols with the others, so that we are required to understand people from different culture. Just like culture differs from one to the other, the practices and behaviour of communication of each person from different culture will also be different.

The concept of acculturation, conceived in the fields of anthropology and sociology early in the 20th century has been used to explain dynamics involved when people from diverse cultural backgrounds come into continuous contact with one another. According to Bourhis \& Carignan (2013), acculturation refers to the process in which the culture of the minorities and the majority influenced and altered by the presence of intercultural contact and they are expected to perform modifications in some aspects of their own culture.

Communication issues may potentially develop in any circumstance or social relationship. It can be easy for individuals to misunderstand or misinterpret others, and these misunderstandings may lead to arguments or tension in personal, platonic, or professional relationships. Communication is truly one of the cornerstones of a healthy relationship. When there is a communication breakdown, many problems may occur in a relationship.

The oral communication includes some aspects ranged in this positions: First. Lexical Choices. Communication will not be effective when the message is not understood. Thus, the capability to pick up the right diction is important in communication. Second is racing (speed). Communication will be more effective and successful if the communciation speed is well managed, not too fast nor too slow. Third, the intonation that will influence the meaning of the message dramatically so that the message will have another meaning by the different intonation. Fourth is the using of humor that can increase the happiness in life with notes, that laughing can help humans to get rid of stress and misery. Laughing relates physics and psychic and can be the only intermezzo in communication. Communication must be short and clear. It will be effective if conveyed clearly and short to be well understood. The last one, the fifth, is timing (the right time to speak) that is very crucial if someone is willing to communicate that means the giving of one's time to listen and be attentive to the things the counterpart is trying to convey. (quoted June 15, 2018, from http://modulmakalah.blogspot.co.id/2015/11/pengertian-proses-dan-hambatan.html).

\section{METHOD.}

This research used qualitative approach. This kind of approach was used to find out the social interaction between the Bataknese and the Javanese in Surabaya. The subjects were chosen from four Bataknese men who are married to the Javanese women. All the procedures of obtaining the data helped me to find out how both the Bataknese and the Javanese communicate and how they reacted, and how they bridged the gap of 
communication to understand each other in their married life. Interviews, observation and recordings the conversations of the four couples were done in doing this research.

The qualified subjects chosen for this research ranged from 40 to 66 years old, had been married for at least 10 years and already had children from this marriage. Finally, they must at least have passed Senior High School to understand and be able to help me in doing this research.

The first subject chosen was Mr Silitonga, 42 years old, was born in Surabaya and got his undergraduate degree in accountancy. He spoke in medium loudness and commented that he could speak loudly when he met another Bataknese.

The next subject was Mr Sihombing, 66 years old Bataknese man who spoke softly, whether at home or with his friends. He was born at Sipirok, South of Tapanuli, and began to travel to Java at the age of 22 years to study and got his degree in electronic at Institute of Technology Surabaya.

The third subject was Mr Ritonga, 60 years old, who began his travel in 1975 after he had finished his high school. Due to his long stay in Java, his voice gradually became softer. He mostly uses the style of speech of directness and asks questions in details.

The last subject was Mr Sinaga, 44 years old, who travelled to Java at the age of 18. He had the highest degree from all the other subjects. He had medium voice but kept using directness and chasing answers in details.

To make it clear which ones of the subjects are Bataknese and which ones are Javanese, I put Bataknese surname for the Bataknese husbands and use the first name for the Javanese wives. All names are pseudonyms and their real identities are hidden, listed in pairs, as follows:

\begin{tabular}{cc}
\hline The Bataknese husbands & The Javanese wives \\
\hline Mr Ritonga & Mrs Nanik \\
Mr Sihombing & Mrs Hana \\
Mr Silitonga & Mrs Ninik \\
Mr Sinaga & Mrs Yessy \\
\hline
\end{tabular}

Table 1. The couples

All the procedure of obtaining the data helped me fnd out how both the Bataknese husbands and the Javanese wives communicate and how they reactred, and how they bridged the gap of communication to understand each other in their married life.

\section{DISCUSSION AND ANALYSIS.}

Communication leads us to meet and exchange symbols with the others and thus we are required to understand others with different culture. As culture differs from one to the other, the practices and behaviour of the humans from those cultures can be different as well. Liliweri (2003) said that in the daily life, no matter where people are, they always interact with certain people belonging from other groups, races, ethnics or cultures. To interact or to communicate with people from different cultures is a new experience they always encounter.

The four Bataknese subjects in this research are Mr Sinaga, Mr Ritonga, Mr Silitonga and Mr Sihombing each with different characteristics in communicating, as they have different degree of loudness, directness and the way they ask questions in details.

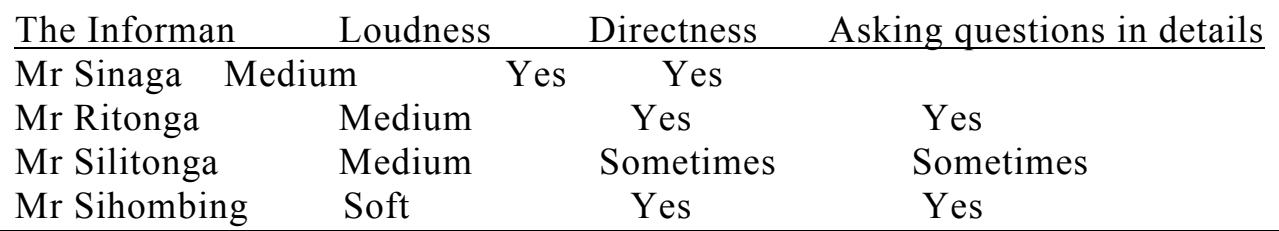

Table 2. Characteristics in communication

This sub heading is used to discuss the findings obtained from interviews and observation from four pairs of subjects, namely the factors that cause the conflicts between the Bataknese husbands and the Javanese wives and how they settle it to explain that the acculturation occurs. 


\section{LOUDNESS OF VOICE COMBINED WITH GESTURES.}

The Bataknese are known as one of the tribes in Indonesia that have loud voice. They almost always use the speaking style of loud voice as if in anger mostly with the pointing of their fore finger, which the Javanese regard as annoying. Moreover, they misjudge it as "impolite". Both Mrs Nanik and Mrs Yessy were irritated by their husbands' loudness of voice with different attitude. Two examples discussed in this part is when both husbands and wives made efforts to solve the conflict by lowering their voice or only thew husband did.

It has become an obstacle in communicating with the Javanese as complained by Mrs Nanik who related the problem of the loudness of voice of her husband, Mr Ritonga, in the early stage of their marriage. Mr Ritonga still often carried the habit of loud voice when speaking although in much lower intensity due to the course of time of living in Surabaya. "Ough. Please turn down your volume. I'm right here beside you. Why do you talk so loudly?", she said relating to the early interaction with her husband in communication. "You sound rude, dear" she said. In answering his wife's remark, $\mathrm{Mr}$ Ritonga replied, "My voice is loud, not rude..." Mrs Nanik was brought up in Javanese tradition known as Njawani which is accustomed to politeness and gentleness. Thus she did not want to have a fight with her husband. From the day onward, instead of giving remarks, Mrs Nanik smiled sweetly toward her husband every time his voice began to increase as a reminder for him to lower the tone. This is the example where husband and wife make effort to understand each other to balance the cross-cultural commnunication problem to end their conflict. Aat this point, acculturation occurs.

Another example concerning the loudness of voice but only the husband who makes effort to lower his voice is Mr Sinaga also spoke loudly in his early stage of marriage with his Javanese wife. He just came to realize the effect of his voice when he saw his wife, Mrs Yessy, covered her both ears with her fingers. It took him some years to lower his voice to show his empathy toward his spouse.

The above happening can be clearly seen from the wife's efforts. They considered their husbands as "rude" or "harsh" due to their loudness of voice. If Mrs Nanik smiled sweetly as a sign to show that her husband spoke too loudly to her, Mrs Yessy only covered both her ears with her fingers and went into her room for hours, At this point, it can be said that the acculturation does not happen.

Two subjects with soft voice are Mr Sihombing as a nomad from North Sumatra and Mr Silitonga who was born in Surabaya. Both can interact more fluently with their Javanese interlocutors due to their soft spoken words and get less difficulties with their Javanese spouses in communicating. The subjects who were born in Java speak softly although the other traits such as speaking to the point and to chase details still become their characteristics.

\section{ANOTHER CAUSE OF CONFLICT IN COMMUNICATION IS DIRECTNESS.}

The nomad Bataknese have the characteristic of speaking "to the point" or directness way of communication, or just "as it is" which is regarded as "rough" and "offending" by their Javanese counterpart or spouse. What is expressed in this way is often interpreted as "very annoying" by the Javanese.

Mr Sihombing is soft spoken but has the habit of speaking to the point and he felt difficult to speak to his wife in this direct style at the early stage of his marriage. In the early stage of his marriage, if he said to his wife such as "Your cooking is not nice today", her reaction would almost always be a frown. She would remark, "How can you be so rough? Why don't you say, 'Your cooking lacks of spices today' instead of 'your cooking is not nice today'?". Mr Sihombing was wondering the difference of both remarks as he thought he had spoken lucidly.

Mr Sinaga also had the same difficulties to communicate with his spouse using the style of directness. He gave an example. "If I said to my wife 'your make-up is to thick', my wife will directly frown and remark, 'Why are you so offending?'. Wondering where he had gone wrong, Mr Sinaga persuaded her to tell him which part of what he said was 
offending. "She said, 'Why can't you tell me, 'Pease have a look into the mirror'." The Javanese are easily offended with the directness of communication. They will manifest it as rough and impolite. What they expect from their spouse is to have the empathy to think of better lexical choice before speaking. Thus both Mr Sihombing and Mr Sinaga acculturated to ease the conflict and adjusted themselves to change his lexical choice when communicating with their wives until they get the balance of adjustment for each other.

Mr Silitonga who is accustomed to be among the Javanese is trying to be careful to choose the words to say to his Javanese wife. When he says something and her reaction is a frown, Mr Silitonga will switch the topic or stop for a time being in order to continue it in next occasion when the time is right. When she does not frown, he will go on as he considers it as being accepted. According to William Howel (1982 in Liliweri, 2003), "Every individual has different level of consciousness and ability to communicate interculturally". Mr Silitonga has the awareness of his lexical choices and chooses them carefully when he mingles with the Javanese community.

The opposite of speaking to the point is speaking indirectly when the Javanese wants to say something but does it convolutedly. It confuses the husband as does $\mathrm{Mr}$ Sihombing experience, as he must guess what his spouse really wants. He gave an example. "When my wife says, 'Ough, it is so awfully hot today. So tiring....' I would answer in the past, when we were still dating, with 'Well, yes, it's so hot' and she would frown. What have I gone wrong, I thought. She would snap and said, 'Take me to the canteen to drink'. Well, this was the way she sulked. A nice convoluted way to say what she actually wanted. Thus the next time she said, 'It is so tiring..', the reaction in my brain was connected to something in the past as she used it as a code for something she wanted, and I said, 'Yeah, let us go to the canteen to drink' and she frowned again. Another misinterpretation? She approached me and nagged, 'Please massage me...' Thus, the way she speaks is indirect and causes a lot of misunderstandings of what she really wants. Many a time I listen to her long and convoluted words and end up without knowing what she actually wants". This is the opposite way of speaking directly which causes confusion and conflict as the husband does not know what his wife really wants.

Mr Sihombing continued, "My wife speaks loudly. It does not matter to me. What matters is the way she conveys what she wants that perplexes me. She does not say directly to the point and she makes it difficult for me to know what she really wants. After we married, I asked her by degree to tell me directly what she actually wanted and did not go round the bush to make me puzzled. It takes time but up to now she sometimes still uses the indirect statement. Just like when she asked me for some more money. She said that she wanted to cook beef soup, my favourite dish. To get the right feed back or right answer, I will ask, 'What is it that you really want to say...?' and thus, she gave the core problem: 'Give me more money.....'

Contacted separately, Mr Sihombing's wife, Mrs Hana,, commented, "I try very hard to speak as politely as I can in order not to offend my husband, but he tells me, instead, to say directly what I really want. We, Javanese, have to speak as nicely as we can, but he cannot accept it. Just like when I need more money for our daily need. I have stopped working, so I do not have spare money in my pocket. I have to ask him".

Liliweri, (2003) said that inter-personal communication style can be explained in cognitive or social mode. Some people have the style of domination while the others choose the submissive way of speaking. Further, Liliweri, ibid, wrote that one of the intercultural communications is to lessen the uncertainties about other person. Within interpersonal encounter, we often come face to face with some ambiguities about relation, at least in the form of: How does he/she feel about me? How does he/she behave toward me? What do I obtain if I communicate with him/her? The questions arising from these statements 'force' people to communicate in order to feel in a certain relation condition, and further to make a decision whether they go on or stop the communication.

Mrs Hana has the njawani attitude. She expects her husband, Mr Sihombing, to understand what she is trying to say behind her statements. She tries to speak indirectly as a way not to hurt her husband or is afraid to be taken as impolite for speaking directly what 
she really wants. Hardly she realizes that what she really means, or implies, is different from what she says. This communication style is really the opposite of the Bataknese attitude in speaking out lucidly and succintly. It is really difficult to communicate according to what the spouse wants to convey due to being used to hold the culture already rooted in oneself. To communicate by means of "beating around the bush" style is regarded as a polite way to say something whereas the spouse conceives the message in the opposite way. It goes the same way if the message is conveyed directly without considering to choose better words to use or to disregard the lexical choice. It will be conceived as annoying or offending. Whether it is not being able to listen effectively to a partner or not being able to communicate feelings, wants or needs, there are many reasons these types of problems may occur. Thus, the using of acculturation combined with empathy or sensitivity is needed over time. The affordances of the couples are figured and refigured as the meaningful connections constituting subjectively felt communication.

STYLE OF COMMUNICATION OF CHASING THE DETAILS.

The Bataknese have the specific communication style to chase the degree of details until the core of the problem is clear. Mrs Nanik, the wife of Mr Ritonga, related how she got insulted by that kind of communication, feeling that she was being interrogated at the early stage of their marriage. It runs as follows:

Mrs Nanik : I met X this morning. She was angry with me

Mr Ritonga : Why was she angry with you?

Mrs Nanik : She heard from Y about her unpaid debt to me.

Mr Ritonga : Why did Y tell her about her unpaid debt to you?

Mrs Nanik $\quad:$ I told $Y$ that I was fexed because she has not paid her debt.

Mr Ritonga : Why has not she paid her debt to you?

Mrs Nanik : I have no idea. She said that she would pay me back within a week.

Mr Ritonga : Why did she not pay you back within a week?

Mrs Nanik : She once said she has no cash yet.

Mr Ritonga : Why did you not ask her directly instead of telling Y about it?

Mrs Nanik : She would say the same answer.

Mr Ritonga : Ask her directly when she can pay her debt. It is much better than saying something behind her back. She may feel humiliated. She may put an end of her friendship with you. She may even talk bad things behind your back.

This kind of Bataknese husband's styles make the Javanese wife, Mrs Nanik, feels insulted. When I interviewed her, Mrs Nanik sighed heavily in telling this. At the early stage of their marriage, she would think this kind of communication as very annoying as she felt she was being treated like a toddler. She felt that she was being interrogated rather than having a conversation between husband and wife. In the lapse of time she eventually realized that her husband wanted to know the background of her deed or speech to help her get the solution. She tried to understand what made her husband ask her the details. This meanss that the Javanese wife made an effort to understand her husband. In this point, acculturation occurs. She said she can accept his style now. Mrs Nanik acculturated to understand his style of communication in solving the displeasure she felt. After having understood, she felt happy and at ease.

\section{CONCLUSION.}

Communication means a lot in the life of people because humans are social beings who need each other. When they communicate, they are expected to have the basic of that communication core to remove the obstacles, especially in marriage. Cultural background makes different ethnics in mix marriage obtain difficulties in the early stages. The primary problem arising from the mix marriage The Javanese dislike or find it hard to accept the communication style of the Bataknese that are loud, direct without proper lexical choices and the chasing of details which the Javanese regard as interrogating and impolite. On the other hand, the Bataknese feel that their Javanese spouse are convoluted, indirect and 
equivocal although their words are conveyed softly and nicely. The Bataknese think that the Javanese spose are convoluted, indirect and equivocal although their words are conveyed softly and nicely. The Bataknesse think that the Javanese try to disguise the true intention of their speech and are so easily offended. So the gap of communication occurs.

The key to bridge the differences in communication between the Bataknese and the Javanese is through acculturation combined with strategy. The Bataknese husbands should have the sensitivity in understanding how their spouse receives their message. On the other hand, their spouse should try to reduce their own sensitivity in receiving the words spoken by their husband. Being over sensitive in responding what others say will increase a feeling of offended that will cause conflicts and unneccesary fights. By understanding the core of the problem that they want to discuss and by realizing the different communication styles due to the difference of culture they have, the mix marriage couple of the Bataknese and the Javanese can be successful which is unfolded in stages.. It takes some practice to improve old marriage communication mistakes. When couples understand how to fit them all together, they can make real progress in their communication.

\section{REFERENCES:}

Adler, A. An Integral Perspective: The Journal of Individual Psychology. Volume 72 Number 4, Winter 2016. University of Texas Press.

Bourhis, Y and Carignan, N. 2013. Materials for Theme 4. Majority relation with Majority Communities. Quebec: Presses De l'1 Iniversite du Quebec. Jan.2013.

Bullmer, K. 1977. A Manual for Improving Accuracy of Interpersonal Perception. New York: United States.

Koentjaraningrat (2002). Pokok Pokok Antropologi Sosial. Jakarta: Dian Rakyat.

Lasswell, Harold (1948). Bryson, L., Ed. The Structure and Function of

Communication in Society. The Communication of Ideas. New York: Harper and Brothers. Last updated: 27 November 2017.

Liliweri, Alo. 2013. Gatra-gatra Komunikasi Antar Budaya. New York: Institute for Religious and Social Studies

Rahardjo, T. (2005), Menghargai Perbedaan Kultural, pp 49-51. Yogyakarta: LkiS

Steinburg, Sheila (2007). An Introduction to Communication Studies. Cape Town: Juta \& Co. p. 53.

Tommy Suprapto.(2006). Pengantar Teori Komunikasi. Yogyakarta: Media Pressindo Vergouwen, J. C. (1986), Masyarakat dan Hukum Adat Batak Toba. Yogyakarta: $\quad$ LkiS (2004)

https://www.caresearch.com.au/caresearch/ForPatientsandFamilies/LivingWithIllness

/WhyIsCommunicationImportant/tabid/1095/Default.aspx.

http://modulmakalah.blogspot.co.id/2015/11/pengertian-proses-dan-hambatan.html. 